\title{
Perbedaan Laju Filtrasi Glomerulus Berdasarkan Kadar Kreatinin dan Cystatin 6 Serum pada Sindrom Nefrotik Anak
}

\author{
Ackni Hartati, Nanan Sekarwana, Dzulfikar DLH \\ Departemen Ilmu Kesehatan Anak Fakultas Kedokteran Universitas Padjadjaran/Rumah Sakit Dr. Hasan \\ Sadikin, Bandung
}

\begin{abstract}
Latar belakang. Komplikasi sindrom nefrotik (SN) yang sering telambat terdeteksi adalah gangguan ginjal akut (GnGA). Cystatin $C$ serum dipertimbangkan menjadi pemeriksaan potensial pengganti kreatinin sebagai penanda fungsi ginjal. Kadar cystatin $C$ lebih mendekati nilai laju filtrasi glomerulus (LFG) dibandingkan dengan kreatinin serum.

Tujuan. Menentukan perbedaan LFG berdasarkan kadar kreatinin dan cystatin $C$ serum pada SN anak. Metode. Penelitian potong lintang dilakukan dari Februari-Maret 2014 di unit rawat jalan dan rawat inap RSUP Dr. Hasan Sadikin Bandung, RSUD Kota Bandung, dan RSUD Cibabat Kota Cimahi. Subjek SN usia 1-14 tahun. Pemeriksaan kadar kreatinin dengan metode Jaffe dan cystatin $C$ serum dengan particleenhanced turbidimetric immunoassay (PETIA). Uji statistik menggunakan McNemar dan uji t berpasangan dan kemaknaan berdasarkan nilai $\mathrm{p}<0,05$.

Hasil. Terdapat 21 kasus SN yang terdiri atas 18 laki-laki dan 3 perempuan dengan rerata usia 6 tahun 3 bulan. Nilai LFG berdasarkan kreatinin $137,86 \pm 27,07 \mathrm{ml} / \mathrm{min} / 1,73 \mathrm{~m}^{2}$ dan LFG berdasarkan cystatin $C$ $73,59 \pm 12,49 \mathrm{ml} / \mathrm{min} / 1,73 \mathrm{~m}^{2}$. Terdapat perbedaan signifikan antara LFG berdasarkan kadar kreatinin dan cystatin $C$ serum $(\mathrm{p}<0,01)$.

Kesimpulan. Proporsi LFG cystatin $C$ berdasarkan formula Filler lebih rendah dibandingkan kreatinin berdasarkan formula Schwartz. Sari Pediatri 2015;16(5):325-9.
\end{abstract}

Kata kunci: sindrom nefrotik, kreatinin, cystatin $C$, laju filtrasi glomerulus

\footnotetext{
Alamat korespondensi:

Dr. Ackni Hartati. Departemen Ilmu Kesehatan Anak Fakultas Kedokteran Universitas Padjadjaran/Rumah Sakit Dr. Hasan Sadikin Bandung, Jl. Pasteur No.38, Bandung 40161. Telp. (022) 2035957, Telepon Seluler 08211-5894742. E-mail: acknicky@yahoo.com
}

indrom nefrotik (SN) merupakan kelainan ginjal yang menjadi rujukan kepada dokter nefrologi anak. Insiden SN cukup tinggi dibandingkan dengan penyakit ginjal lainnya karena kronisitas dan evaluasi serta penanganannya. ${ }^{1}$ Proteinuria merupakan gejala 
utama pasien SN, sedangkan gejala lain seperti edema, hipoalbuminemia, dan hiperlipidemia bersifat sekunder terhadap proteinuria. ${ }^{2-4}$ Kelainan yang mendasari SN adalah kerusakan membran kapiler glomerulus yang menyebabkan proteinuria masif dan hipoalbuminemia. ${ }^{4-6}$ Hipoalbuminemia menyebabkan cairan berpindah dari kompartemen intravaskular ke interstitial dan menyebabkan hipovolemia. ${ }^{7,8}$ Hipovolemia yang timbul akibat hipoalbuminemia menyebabkan penurunan volume darah sirkulasi sehingga aliran darah ke ginjal (volume darah yang masuk ke glomerulus) menjadi lebih sedikit. ${ }^{4}$ Gangguan ginjal akut (GnGA) merupakan salah satu komplikasi dari SN yang sering dipresipitasi oleh hipovolemia dan ditandai dengan adanya penurunan LFG. ${ }^{8-10}$

Teknik untuk menilai LFG dapat dilakukan dengan penanda endogen dan eksogen. Penanda eksogen adalah inulin, 51-cr-EDTA, 99mTc lebeled diethylene triamine penta acetic acid (DTPA) or 125labeled iothalamate. Penanda endogen yang sering digunakan adalah kreatinin, cystatin $C$, $\beta$-trace protein, $\beta_{2}$-microglobulin, neutrophil gelatinase-associated lipocalin (NGAL), dan lain-lain. ${ }^{11}$ Penanda eksogen, seperti pemeriksaan klirens inulin yang merupakan baku emas untuk penilaian LFG, jarang digunakan karena memerlukan waktu lama, tenaga ahli, dan biaya yang mahal dibandingkan dengan penanda filtrasi endogen (kreatinin dan cystatin C) sehingga tidak ideal untuk digunakan dalam praktik klinis sehari-hari. ${ }^{12}$ Oleh karena itu, diperlukan penanda filtrasi endogen yang lebih sederhana dan memberikan hasil cepat dan tepat.

Kreatinin adalah penanda endogen LFG yang merupakan suatu asam amino derivat dengan berat molekul 113 Dalton dan secara bebas difiltrasi oleh glomerulus. Banyak penelitian yang melaporkan kesetaraan klirens kreatinin dengan LFG dan mempunyai korelasi yang kuat dengan kadar kreatinin serum. Kreatinin disekresi oleh sel-sel tubulus proksimal, sama halnya dengan yang difiltrasi oleh glomerulus sehingga klirens kreatinin melampaui nilai LFG. ${ }^{13}$ Cystatin $C$ atau human gamma trace dalam non-glycosilated basic protein berfungsi sebagai inhibitor terhadap sistem protease dan tersebar luas di dalam cairan tubuh. Cystatin $C$ merupakan suatu protein endogen atau protein non-glycosilated rantai tunggal yang terdiri atas 120 asam amino dengan berat molekul 13,36 kDa dengan karakteristik ikatan
2 disulfida pada bagian terminal karboksil. ${ }^{14}$ Cystatin $C$ merupakan protein endogen yang difiltrasi oleh glomerulus dan diabsorpsi serta dikatabolisme oleh sel epitelial tubuler, kemudian diekskresikan ke dalam urin dalam jumlah sangat sedikit. Kadar cystatin $C$ dalam serum menggambarkan LFG yang mendekati penanda LFG endogen ideal.

Penelitian Cordeiro dkk ${ }^{15}$ melaporkan terdapat korelasi antara kadar kreatinin dan cystatin $C$ serum pada penderita anak dengan berbagai penyakit ginjal. Penelitian lainnya yang dilakukan oleh Murty $\mathrm{dkk}^{16}$ terhadap penderita gangguan ginjal akut dewasa didapatkan cystatin $C$ lebih sensitif dalam menilai adanya gangguan ginjal akut pada dewasa.

Penelitian ini bertujuan untuk menentukan perbedaan LFG berdasarkan kadar kreatinin dan cystatin $C$ serum pada penderita $\mathrm{SN}$ anak.

\section{Metode}

Subjek penelitian adalah pasien SN idiopatik anak usia 1-14 tahun yang dirawat di RSUP Dr. Hasan Sadikin Bandung, RSUD kota Bandung dan RSUD Cibabat Kota Cimahi. Pengambilan sampel dilakukan secara consecutive hingga jumlah subjek terpenuhi. Subjek dengan hipotiroid, hipertiroid, penyakit ginjal kronik, dan infeksi saluran kemih dieksklusikan dari penelitian. Penelitian dilakukan secara observasi analitik dengan rancangan potong lintang (cross sectional). Beberapa data karakteristik subjek penelitian, meliputi umur, jenis kelamin, berat badan dan tinggi badan serta diagnosis diambil dari catatan rekam medis. Fungsi ginjal pasien dihitung berdasarkan estimasi laju filtrasi glomerulus (eLFG) dengan formula Schwartz $(0,413 \mathrm{x}$ tinggi badan $(\mathrm{cm}) /$ kreatinin serum $(\mathrm{mg} / \mathrm{dL})$ untuk kreatinin dan Filler $\left(66,22 \times(1 / \text { cystatin } C(\mathrm{mg} / \mathrm{L}))^{0,777}\right.$ untuk cystatin $C$. Variabel yang diteliti adalah kadar kreatinin, cystatin $C$, serum, LFG berdasarkan formula Filler dan LFG berdasarkan formula Schwartz. Pemeriksaan kreatinin menggunakan metode Jaffe dan cystatin $C$ dengan metode particle enhanced turbdimteric immunoassay (PETIA). Analisis statistik untuk melihat proporsi LFG berdasarkan formula Filler dan Schwartz dinilai dengan uji McNemar serta untuk menilai perbandingan antara LFG berdasarkan formula Filler dengan Schwartz menggunakan uji t berpasangan. 


\section{Hasil}

Selama periode penelitian bulan Februari hingga Maret 2014 terdapat 21 kasus sindrom nefrotik idiopatik anak yang memenuhi kriteria penelitian. Karakteristik umum subjek penelitian dan laboratorium penelitian tertera pada Tabel 1 . Terlihat sebagian besar laki-laki dan diagnosis terbanyak adalah $\mathrm{SN}$ resisten steroid.

Tabel 2 memperlihatkan LFG menurut kreatinin dan cystatin $C$ berdasarkan berat badan dan tinggi badan. Secara statistik tidak terdapat perbedaan yang bermakna baik untuk LFG berdasarkan kreatinin maupun cystatin $C$. Proporsi LFG berdasarkan kreatinin dan cystatin $C$ pada pasien $S N$ anak tertera pada Tabel 3. Pada pasien SN, nilai LFG berdasarkan cystatin $C$ hampir semuanya menurun dengan nilai LFG berdasarkan kreatinin masih dalam batas normal.

Analisis perbedaan antara nilai LFG berdasarkan kreatinin 137,86 $(27,07) \mathrm{ml} / \mathrm{min} / 1,73 \mathrm{~m}^{2}$ dan cystatin $C 73,59(12,49) \mathrm{ml} / \mathrm{min} / 1,73 \mathrm{~m}^{2}$ pasien $\mathrm{SN}$ anak dengan menggunakan uji t berpasangan menunjukkan perbedaan yang signifikan.

\section{Pembahasan}

Pada penderita SN, gangguan ginjal akut merupakan salah satu komplikasi. Patogenesis terjadinya GnGA karena timbulnya keadaan hipovolemia disebabkan hipoalbuminemia yang ditandai dengan penurunan

Tabel 1. Karakteristik subjek penelitian

\begin{tabular}{lc}
\hline Karakteristik & $\mathrm{n}$ \\
\hline Jenis kelamin & \\
Laki-laki & 18 \\
$\quad$ Perempuan & 3 \\
Usia (tahun, rerata (SB)) & $6,33(2,517)$ \\
$\quad$ Median & 6 \\
Rentang & $(3-13)$ \\
Diagnosis (n) & \\
SN resisten steroid & 10 \\
SN serangan pertama & 5 \\
SN relaps jarang & 4 \\
SN dependent steroid & 1 \\
SN relaps sering & 1 \\
\hline
\end{tabular}

Keterangan: n=jumlah sampel, SB: simpangan baku

Tabel 2. Faktor yang berhubungan dengan laju filtrasi glomerulus

\begin{tabular}{lccccc}
\hline Variabel & $\mathrm{n}$ & LFG kreatinin & $\mathrm{p}$ & LFG cystatin $C$ & $\mathrm{p}$ \\
\hline Berat badan(kg) & & & & & \\
$13-21$ & 12 & $146,17 \pm 27,6$ & $\left.0,240^{* *}\right)$ & $76,47 \pm 11,98$ & $\left.0,465^{* *}\right)$ \\
$22-30$ & 6 & $123,33 \pm 23,9$ & & $70,88 \pm 15,1$ & \\
31-49 & 3 & $133,67 \pm 25,3$ & & $67,5 \pm 8,4$ & \\
Tinggi badan(cm) & & & & \\
$87-99$ & 5 & $147,8 \pm 35,9$ & $\left.0,082^{* *}\right)$ & $79,13 \pm 14,8$ & $\left.0,584^{* *}\right)$ \\
$100-113$ & 8 & $139,37 \pm 20,1$ & & $74,6 \pm 11,3$ & \\
$114-126$ & 6 & $142,5 \pm 18,6$ & & $68,5 \pm 14,2$ & \\
$127-139$ & 2 & $93 \pm 16,97$ & & $70,77 \pm 4,2$ \\
\hline
\end{tabular}

Keterangan: ANOVA* $^{*}$ rerata \pm SB

Tabel 3. Proporsi laju filtrasi glomerulus berdasarkan kreatinin dan cystatin $C$ pada SN anak

\begin{tabular}{|c|c|c|c|c|c|c|}
\hline \multirow{2}{*}{ Variabel } & \multirow{2}{*}{$\mathrm{n}$} & \multicolumn{2}{|c|}{ Kreatinin } & \multicolumn{2}{|c|}{ Cystatin $C$} & \multirow{2}{*}{$\mathrm{p}^{*}$} \\
\hline & & LFG Normal & LFG Rendah & LFG Normal & LFG Rendah & \\
\hline Sindrom nefrotik & 21 & 20 & 1 & 1 & 20 & 0,001 \\
\hline $\begin{array}{ll}\text { Keterangan: } & \text { LFG R } \\
& \text { LFG N }\end{array}$ & $\begin{array}{l}1,73 \\
1,73\end{array}$ & & & & & \\
\hline
\end{tabular}


LFG. ${ }^{10,12,13}$ Penilaian LFG dapat dilakukan berdasarkan kadar kreatinin dan cystatin $C$ serum. ${ }^{16}$

Pengukuran LFG (laju filtrasi glomerulus) dengan kreatinin menggunakan rumus formula Schwartz memiliki nilai lebih tinggi dibandingkan cystatin $C$ rumus formula Filler. Hal tersebut sesuai dengan hasil penelitian Cordeiro dkk, ${ }^{15}$ di Brazil, yang melaporkan bahwa cystatin Clebih sensitif dalam menilai LFG pada pasien dengan kelainan ginjal. Penelitian observasi cross-sectional tersebut dilakukan terhadap 254 anak dengan penyakit ginjal dan 19 tanpa penyakit ginjal yang berusia 2 hingga 18 tahun. Pada penelitian tersebut didapat 134 anak laki-laki dan 120 perempuan yang memiliki penyakit ginjal-SN (16,5\%), glomerulonefritis akut $(11,4 \%)$, neurogenic bladder $(11,4 \%)$, gagal ginjal kronik $(5,9 \%)$, hidronefrosis $(9,8 \%)$, hematuria asimtomatik (11\%), dan penyakit lainnya (11\%)-dengan membandingkan kadar kreatinin dan cystatin $C$ serum untuk estimasi LFG pada anak.

Nilai LFG berdasarkan kreatinin dengan menggunakan rumus Schwartz, GFR $<90 \mathrm{ml} / \mathrm{min} / 1,73 \mathrm{~m}^{2}$ didapatkan pada 1 dari 21 pasien. Nilai rerata LFG kreatinin $137,86 \pm 27,07 \mathrm{ml} / \mathrm{min} / 1,73 \mathrm{~m}^{2}$. Hasil tersebut sesuai dengan penelitian yang dilakukan di Brazil tahun 2008 dengan hasil rerata nilai LFG kreatinin $138 \pm 4 \mathrm{ml} /$ $\min / 1.73 \mathrm{~m}^{2}$. Kadar kreatinin normal dapat disebabkan karena kreatinin memiliki jalur eliminasi alternatif, kreatinin akan mengompensasi penurunan LFG dan menyebabkan kadarnya tidak berubah sampai terjadi penurunan sebesar $\pm 50 \%$ dari LFG. Kadar kreatinin akan meningkat apabila kapasitas dari jalur sekresi tubulus alternatif ini telah seluruhnya digunakan. Hal tersebut menyebabkan adanya creatinine blind range yang membuat sensitivitas dan menetapnya kadar kreatinin pada penurunan LFG normal. ${ }^{14,17}$

Nilai LFG berdasarkan cystatin $C$ mengalami penurunan fungsi ginjal dibandingkan dengan nilai LFG berdasarkan kreatinin $(73,59 \pm 12,49 \mathrm{ml} / \mathrm{min} / 1,73$ $\mathrm{m}^{2}$ ). Hal tersebut sesuai dengan penelitian tahun 2008 di Brazil dengan nilai LFG berdasarkan cystatin $C$ adalah $88 \pm 36 \mathrm{ml} / \mathrm{min} / 1,73 \mathrm{~m}^{2}$ ). Penelitian sebelumnya, di India tahun 2008 sampai 2010, terhadap 200 pasien dewasa sehat dan 130 pasien dewasa dengan GnGA juga didapatkan hasil yang sama dengan nilai rerata LFG berdasarkan cystatin $C .{ }^{16}$ Penurunan nilai LFG berdasarkan cystatin $C$ terjadi karena cystatin $C$ serum mengalami eliminasi eksklusif melalui filtrasi glomerulus sehingga merupakan penanda ideal LFG, sedangkan kreatinin selain diekskresikan di ginjal melalui proses filtrasi glomerulus juga mengalami sekresi di tubulus ginjal. Faktor lain yang saat ini dianggap memengaruhi kadar kreatinin adalah tinggi badan subjek. Sebaliknya, penilaian LFG berdasarkan cystatin $C$ tidak dipengaruhi oleh tinggi badan sehingga lebih sensitif menilai LFG. ${ }^{17,18}$

Nilai LFG berdasarkan kreatinin dan cystatin $\mathrm{C}$ tidak dipengaruhi oleh tinggi badan. Hasil ini tidak sesuai dengan teori ataupun penelitian yang dilakukan di Brazil dengan nilai LFG berdasarkan kreatinin seharusnya dipengaruhi oleh tinggi badan. Hal tersebut dapat terjadi, kemungkinan, dikarenakan sampel penelitian yang sedikit dibandingkan dengan penelitian sebelumnya. Penelitian lain juga menyatakan bahwa cystatin $C$ lebih baik dibandingkan kreatinin dalam mendeteksi gangguan ginjal ringan untuk penilaian LFG. Saat nilai kreatinin masih dalam batas normal dan perkiraan nilai LFG-nya juga dalam batas normal. ${ }^{18,19} \mathrm{Hal}$ tersebut sangat penting untuk pasien dengan penyakit gangguan ginjal pada fase awal, saat evaluasi laboratorium adalah satu-satunya pemeriksaan untuk mendeteksi adanya penyakit karena apabila terlambat akan menyebabkan penyakit ginjal yang progresif dan menetap. ${ }^{20,21}$

Keterbatasan penelitian adalah fungsi ginjal subjek penelitian tidak diperiksa menggunakan metode baku emas untuk konfirmasi keadaan fungsi ginjal sebenarnya, yaitu dengan menggunakan klirens inulin.

\section{Kesimpulan}

Terdapat perbedaan bermakna antara LFG berdasarkan kadar kreatinin dibandingkan dengan cystatin $C$ serum pada SN anak.

\section{Daftar pustaka}

1. Niaudet P, Boyer O. Idiopathic nephrotic syndrome in children: clinical aspects. Dalam: Avner ED, Harmon WE, Niaudet P, Yoshikawa N, penyunting. Pediatric nephrology. Edisi ke- 6. Berlin: Springer;2009. h.731-47.

2. Bagga A, Mantan M. Nephrotic syndrome in children. Indian J Med Res 2005;122:13-28.

3. Davin JC, Rutjes NW. Nephrotic syndrome in children: from bench to treatment. Int J Nephrol 2011;2011:16.

4. Haycock G. The child with idiopathic nephrotic 
syndrome. Dalam: Webb N, Postlethwait R, penyunting. Clinical paediatric nephrology. Edisi ke- 3. New York: Oxford;2003.h.340-66.

5. Pais P, Avner ED. Fixed proteinuria. Dalam: Kliegman RM, Stanton BF, Schor NF, Behrman RE, penyunting. Nelson Textbook of Pediatrics. Edisi ke-19. Philadelphia: Elsevier Saunders; 2011. h.897-8.

6. Pais P, Avner ED. Nephrotic syndrome. Dalam: Kliegman RM, Stanton BF, Schor NF, Behrman RE, penyunting. Nelson Textbook of Pediatrics. Edisi ke-19. Philadelphia: Elsevier Saunders; 2011. h.898-900.

7. Soni N. Wonderful albumin? Br Med J 1995;310:8878.

8. Lowenberg EKM, Berg UB. Influence of serum albumin on renal function in nephrotic syndrome. Pediatr Nephrol 1999;13:19-25.

9. Berg U, Bohlin AB. Renal hemodynamics in minimal change nephrotic syndrome in childhood. Int J Pediatr Nephrol 1982;3:187-92.

10. Agarwal N, Phadke KD, Garg I, Alexander P. Acute renal failure in children with idiopathic nephrotic syndrome. Pediatr Nephrol 2003;18:1289-92.

11. Filler G, Priem F, Lepage N, Sinha P, Vollmer I, Clark H. $\beta$-trace protein, cystatin $C, \beta 2$ microglobulin, and creatinine compared detecting impaired glomerular filtration rates in children. Clin Chem 2002;48:72936.

12. Stevens LA, Coresh J, Greene T, Levey AS. Assesing kidney function-measured and estimated glomerular filtration rate. N Engl J Med 2006;354:2473-83.

13. Rodwell VW. Metabolism of protein and amino acids
Dalam: Murray RK, Granner DK, Moyes PA, Rodwell VW, penyunting. Harper's illustrated biochemistry. Edisi ke-2. New York: Mc.Grawhill Inc;2003.h.237-42.

14. Mussap M, Plebani M. Biochemistry and clinical role of human cystatin C. Crit Rev Clin Lab Sci 2004;41:467550.

15. Cordeiro VF, Pinhiero DCSN, Silva GB, Lima JWO, Mota RM. Comparative study of cystatin $\mathrm{C}$ and serum creatinine in the estimative of glomerular filtration rate in chidren. Clinica Chimica Acta 2008;391:46-50.

16. Murty MSN, Sharma UK, Pandey VB, Kankare SB. Serum cystatin $\mathrm{C}$ as a marker of renal function in detection of early acute kidney injury. Indian J Nephrol 2013;23:180-3.

17. Brguljan PM, Cimerman N. Human Cystatin C. Turk J Biochem 2007;32:95-103.

18. Reinhard M, Erlandsen EJ, Randers E. Biological variations of cystatin c and creatinine. Scand J Clin Lab Invest 2009;69:831-6.

19. Filler G, Bokenhamp A, Hofmann W, Bricon TL, Martinez-Bru C, Grubb A. Cystatin C as a marker of GFR-history, indications, and future research. J Clin Biochem 2005;38:1-8.

20. Randers E, Kristensen JH, Erlandsen SJ, Danielsen H. Serum cystatin C as a marker of the renal function. Scand J Clin Lab Invest 1998;58:585-92.

21. Randers E, Erlandsen EJ, Pedersen OL, Hasling C, Danielsen H. Serum cystatin $\mathrm{C}$ as an endogenous parameter of the renal function in patients with normal to moderately impaired kidney function. Clin Nephrol 2000;54:203. 